\title{
Idéias dentro e fora do lugar
}

Domenico De Masi, professor de sociologia da Universidade La Sapienza, de Roma, é conhecido no Brasil por seus trabalhos sobre criatividade, tempo livre e sociedade pós-industrial. Quem conhece um pouco a Itália não se espanta que essas idéias sejam defendidas por um italiano. No meu entender, é o típico caso de um contexto cultural exercer forte influência sobre as idéias: são as idéias dentro do lugar.

\section{SENSO ESTÉTICO}

A primeira impressão que tenho da sociedade italiana é que o senso estético inunda todos os vínculos sociais. Por lá, quando eles gostam de um filme (mesmo os de terror), não dizem que ele é bom - como dizemos por aqui - mas que é bello, uma das palavras mais usadas por eles. Outra característica que noto é levar a sério o tempo livre (tempo libero), uma expressão também muito usada. É o tempo do não trabalho, que aproveitam para freqüentar as praças públicas a partir das 17 horas, por exemplo. Em Milão, as praças são lugares onde as pessoas podem caminhar e "dar um tempo", ou ainda conversar, comer e beber algo. E eles sabem muito bem comer e beber.

\section{LUGAR CERTO}

$\mathrm{E}$ isso me faz pensar se as idéias de De Masi não ficariam um pouco fora de lugar no Brasil. De fato, elas são muito atraentes, mas me pergunto sobre a qualidade de nosso tempo livre, quando o temos. Uma questão crucial, a meu ver, é que nossos espaços públicos, onde poderíamos usufruir desse tempo, estão degradados: são feios, muitas vezes distantes e não oferecem segurança. Há muito a praça deixou de ser lugar de encontro e pertença à cidade. O que deveria ser regra, é privilégio: sentar em um banco de praça sem ser perturbado ou ter medo de ser assaltado. Talvez a palavra "deveria" seja a chave. Quando uma idéia está dentro do lugar, é possibilidade. Mas quando uma idéia está fora do lugar, vira desejo e, assim, "gostaríamos" e "deveríamos" ter essa possibilidade. E, dessa forma, continuamos a aguardar o futuro, nem que seja o do pretérito.
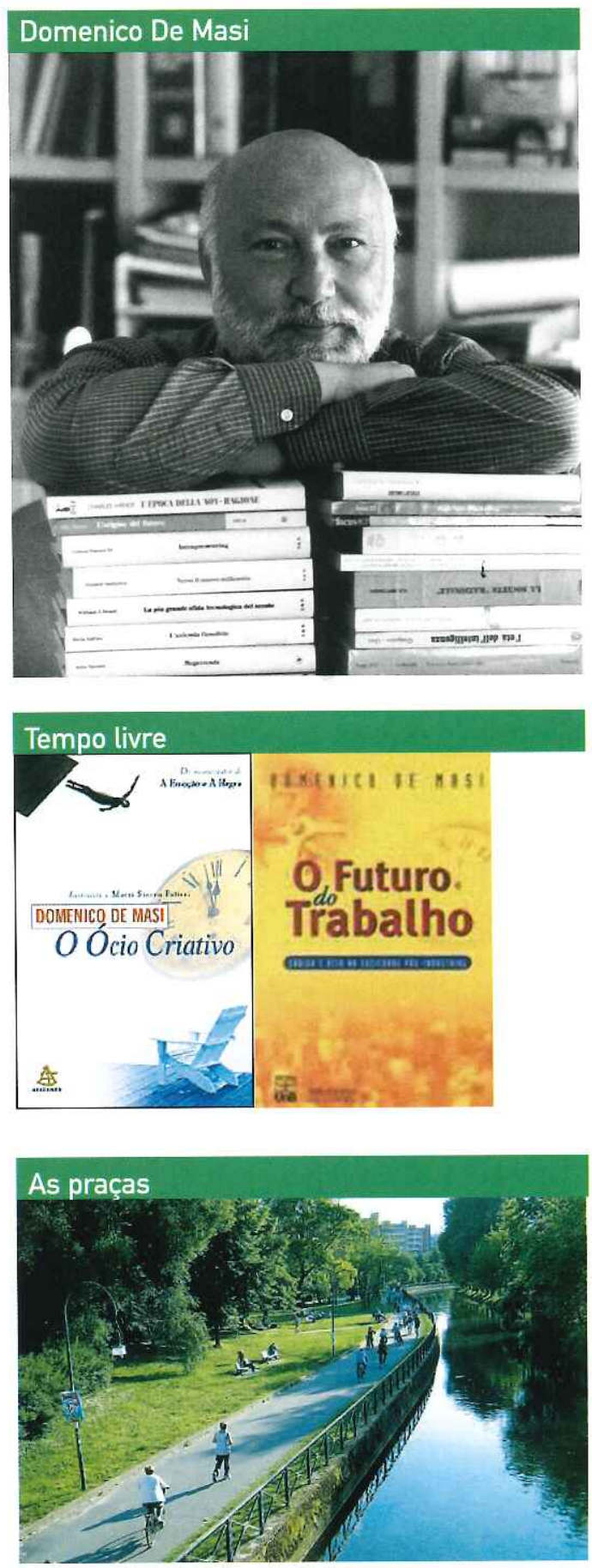